\title{
Contents, Vol. 173, 1986
}

\section{No. 1 Editorial}

Which Laser for What?

Polla, L.L 1

Pharmacology and Treatment

Terfenadine and Brompheniramine Maleate in Urticaria and Dermographism

Ormerod, A.D.; Baker, R.; Watt, J.; White, M.I 5

Case Report

Partial Lipodystrophy, Meningococcal Meningitis and Nephritis

Schifferli, J.A.; Blanc, E 9

Short Communication

Bone Marrow Investigation in Patients with Lichen planus

Nordlind, K.; Lagerholm, B.; Hast, R.; Strand, A 13

Letter to the Editor

Autosomal Recessive Epidermolysis Bullosa of the Albopapuloid Type

Prigent, F 16

Ramelet, A.-A.; Boillat, C 16

67. Jahresversammlung der Schweizerischen Gesellschaft für Dermatologie und Venereologie

18. und 19. Oktober in Zurich

67e Reunion annuelle de la Société Suisse de Dermatologie et de Venereologie

18 et 19 octobre à Zurich

Klinische Demonstrationen - Presentation de cas cliniques

Demonstrationen der Dermatologischen Universitätsklinik Zurich

Schnyder, U.W.; Panizzon, R.; Sigg, C; Schneider, B.V 17

'Soforttyp'-Reaktionen auf Pyrazol-Derivate: Ergebnisse von Hauttesten und Antikörperbestimmungen

Wüthrich, B.; Fabro, L.; Wälti, M 24

Demonstrationen der Dermatologischen Universitätsklinik Bern

Krebs, A.; Zala, L.; Hunziker, T.; Kunz, E.; Brunner, F 29

Demonstrationen der Dermatologischen Universitätsklinik Basel

Büchner, S.; Neeser, P.; Rufli, T 38

Presentation de cas cliniques de la Clinique Universitaire de Dermato-Vénéréologie de

Lausanne

Ruffieux, C; Perroulaz, G.; Frenk, E 43

Book Review 52

No. 2 Editorial

Rosacea: Disease or Reaction Pattern?

Ramelet, A.-A 53

Clinical and Laboratory Investigations

Alcohol Consumption and Psoriasis 
Monk, B.E.; Neill, S.M

Contents III

Follicule to Follicule Heterogeneity of Sebum Excretion

Piérard, G.E 61

Tyrosinemia Type II in Two Cases Previously Reported as Richner-Hanhart Syndrome

Balato, N.; Cusano, F.; Lembo, G.; Santoianni, P 66

Pharmacology and Treatment

Failure of Etretinate in Epidermodysplasia verruciformis

Kowalzick, L.; Mensing, $\mathrm{H} \quad 75$

Hypotheses and Comments

Expert Systems in Dermatology: The Computer Potential. The Example of Facial Tumour

Diagnosis

Finlay, A.Y.; Hammond, P 79

Case Reports

Sweet's Syndrome Associated with Yersinia enterocolitica Infection

Eisner, P.; Hartmann, A.A.; Lechner, W 85

Kasabach-Merritt Syndrome with Disseminated Intravascular Coagulopathy Treated by

Exchange Transfusion and Surgical Excision

Tanaka, K.; Shimao, S.; Okada, T.; Tanaka, A 90

New Primary Malignant Melanoma, Epidermotropism and Indian-File Arrangement of Metastatic Tumor Cells in a Case with Intransit Metastases of Acral Type of Malignant Melanoma

Kato, T.; Demitsu, T.; Tomita, Y.; Tagami, H 95

Letters to the Editor

Neurofibromatosis in a Scar

Ingber, A.; Grunwald, M.H.; Feuerman, E.J.; Sandbank, M 101

Alopecia universalis and Kallman's Syndrome

Monk, B 101

Ritodrine and Pyridoxine in Herpes gestationis

Costa, C; Posternak, F.-R 103

Co-Existing Vitiligo and Small-Plaque Parapsoriasis

Enhamre, A.; Ros, A.-M.; Nordlind, K 103

No. 3 Hypotheses and Comments

How to Manage Psoriasis of the Eyelids. A Glance at Opinions of Other Dermatologists

Wolf, R 105

Clinical and Laboratory Investigations

HLA in Familial Malignant Melanoma

Boullie, M.C.; Thomine, E.; Demenais, F.; Daveau, M.; Laurent, P 109

Solar Urticaria without Inhibitory Spectrum: Demonstration of Both Circulating Photoallergen and Reaginic Antibodies

Torinuki, W.; Tagami, H 116

Hepatic Disease in Erythropoietic Protoporphyria

Mooyaart, B.R.; Jong, G.M.Th. de; Veen, S. van der; Driessen, L.H.H.M.; Beukeveld, G.J.J.; Grond, J.; Gips, C.H 120

Mycosis Fungoides and Sézary's Syndrome Show Distinct Histomorphological Features Imai, S.; Burg, G.; Braun-Falco, 0131 
IV Contents

Pharmacology and Treatment

Topical Minoxidil Useful in 18\% of Patients with Androgenetic Alopecia: A Study of 430

Cases

Tosti, A 136

Response of Male Acne to Antiandrogen Therapy with Cyproterone Acetate

Misch, K.J.; Dolman, W.F.G.; Neild, V.; Rhodes, E.L 139

Acupuncture and Pain in Dermatology

Nielsen, M 143

Case Reports

Subacute Lupus erythematosus-like Gyrate Erythema. Report of a Case Associated with a

Breast Cancer

Neumann, R.; Schmidt, J.B.; Niebauer, G 146

Disseminated Epidermolytic Acanthoma Revealed by PUVA

Nakagawa, T.; Nishimoto, M.; Takaiwa, T 150

Letters to the Editor

Anapsos Modifies Immunological Parameters and Improves the Clinical Course in Atopic

Dermatitis

Jimenez, D.; Doblare, E.; Naranjo, R.; Muñoz, C; Vargas, J.F 154

Genital Tuberculids - An Appropriate Term

Ramesh, V 155

Penis Tuberculides: Papulonecrotic Tuberculides on the Glans penis

Nishigori, C 156

No. 4 Clinical and Laboratory Investigations

Extrapituitary Neuroendocrine Melanoderma

Al Rustom, K.; Gerard, J.; Piérard, G.E 157

Skin Cellular Retinoid-Binding Proteins and Retinoid-Responsive Dermatoses

Siegenthaler, G.; Saurat, J.-H.; Salomon, D.; Mérot, Y 163

Triple Extramammary Paget's Disease. Immunohistochemical Studies

Hashimoto, T.; Inamoto, N.; Nakamura, K 174

Acute Generalized Exanthematous Pustular Dermatitis and Viral Infection

Rouchouse, B.; Bonnefoy, M.; Pallot, B.; Jacquelin, L.; Dimoux-Dime, G.; Claudy, A.L. 180

Rapid Communication

Photoonycholysis Induced by the Fluoroquinolones Pefloxacine and Ofloxacine. Report on

2 Cases

Baran, R.; Brun, P 185

Case Report

Symmetrical Peripheral Gangrene in Disseminated Tuberculosis

Itin, P.; Stalder, 1·L; Vischer, W 189

Letters to the Editor

Follow-Up of Patients with Epidermodysplasia verruciformis Treated with Etretinate

Jablonska, S.; Obalek, S.; Wolska, H 196

Contents

$\mathrm{V}$

Sudan-IV-Positive Material in Fingernails of Patient Affected with Mai de Meleda

Salamon, T 199 
Retroviruses and Pemphigus

Hunziker, T.; Schilt, U

Society Proceedings

Prurigo pigmentosa: 3rd Non-Japanese Case

Harms, M.; Mérot, Y.; Polla, L.; Saurat, J.-H202

Evaluation of Prophylactic Benzathine-Penicillin in the Prevention of Recurrent Erysipelas

Duvanel, T.; Harms, M.; Mérot, Y.; Saurat, J.-H 205

No. 5 Clinical and Laboratory Investigations

Plasma Zinc Is Decreased Only in Generalized Pustular Psoriasis

Dreno, B.; Vandermeeren, M.A.; Boiteau, H.L.; Stalder, J.F.; Barrière, H 209

Complement Fixation by Brazilian Pemphigus foliaceus Antibodies in vitro

Shimizu, H.; Nishikawa, T 213

Serum C-Reactive Protein Measurement in Pyoderma gangrenosum

Rowe, I.F.; Deans, A.C 216

Pharmacology and Treatment

Long-Term Oral Acyclovir Treatment Prevents Recurrent Genital Herpes

Blom, I.; Back, O.; Egelrud, T.; Frödin, T.; Hellbe, L.; Johannisson, G.; Malmros-

Enander, I.; Molin, L 220

Solar Urticaria: A Case with Good Therapeutic Response to Cimetidine

Tokura, Y.; Takigawa, M.; Yamauchi, T.; Yamada, M 224

Ketoconazole Treatment of 13 Patients with Chronic Mucocutaneous Candidiasis. A Pros pective 3-Year Trial

Mobacken, H.; Moberg, S 229

Evaluation of Cefotetan in Uncomplicated Gonorrhea

Korting, H.C.; Abeck, D.; Neubert, U 237

Case Reports

Basal Cell Nevus Syndrome and Webbed Neck

Boer, E.M. de; Bruynzeel, D.P 245

Captopril-Induced Lichen planus pemphigoides with Pemphigus-Like Features. A Case

Report

Flageul, B.; Foldes, C; Wallach, D.; Vignon-Pennamen, M.D.; Cottenot, F 248

Letters to the Editor

Phenobarbital-Induced Pemphigus vulgaris

Dourmishev, A.L.; Rahman, M.A 256

Transient Rhabdomyolysis Connected with Topical Use of 5-Fluorouracil in a Patient with Psoriasis of the Nails

Schmied, E.; Levy, P.M 257

Mini Book Reviews 259

260

Announcements

VI

Contents

No. 6

Editorial

Anthralin Shroot, B. 
261

Clinical and Laboratory Investigations

Pathogenetic Studies in Chronic Urticaria. Failure to Demonstrate Vasculitis, Complement

Activation and Fibrinolysis

Boonk, W.J.; Nieboer, C; Huijgens, P.C 264

Natural History of Dermatitis herpetiformis in Southern Sweden

Christensen, O.B.; Hindsén, M.; Svensson, A 271

Exfoliative Dermatitis. A. Prospective Study of 80 Patients

Sehgal, V.N.; Srivastava, G 278

Pharmacology and Treatment

Treatment of Psoriasis with Dithranol Cream Compared with Dithranol Paste

Young, E 285

Irritant Potential of Dithranol

Haustein, U.-F.; Lohrisch, 1288

Case Report

Atypical Lichen planus Associated with Ulcerative Colitis

Cox, N.H.; Finlay, A.Y.; Watkinson, G 294

Rapid Communication

Dysplastic Nevus Syndrome: Ultraviolet Hypermutability Confirmed in vitro by Elevated

Sister Chromatid Exchanges

Jung, E.G.; Bohnert, E.; Boonen, H 297

Letter to the Editor

Minoxidil Induces Selective Regrowth of Androgenetic Dependent Hair

Ramelet, A.-A 301

Acknowledgement to Reviewers 303

Author Index 306

Subject Index 308

S. Karger $\cdot$ Medical and Scientific Publishers

Basel $\cdot$ München $\cdot$ Paris $\cdot$ London $\cdot$ New York $\cdot$ New Delhi $\cdot$ Singapore $\cdot$ Tokyo $\square$ Sydney

Drug Dosage

The authors and the publisher have exerted every effort to ensure that drug selection and dosage set forth in this text are in accord with current recommendations and practice at the time of publication. However, in view of ongoing research, changes in government regulations, and the constant flow of information relating to drug therapy and drug reactions, the reader is urged to check the package insert for each drug for any change in indications and dosage and for added warnings and precautions. This is particularly important when the recommended agent is a new and/or infrequently employed drug.

All rights reserved.

No part of this publication may be translated into other languages, reproduced or utilized in any form or by any means, electronic or mechanical, including photocopying, recording, microcopying, or by any information storage and retrieval system, without permission in writing from the publisher or, in the case of photocopying, direct payment of a specified fee to the Copyright Clearance Center (see 'Information for Readers and Subscribers').

(C) Copyright 1986 by

S. Karger AG, P.O. Box, CH-4009 Basel (Switzerland) Printed in Switzerland by Werner Druck AG, Basel 